\title{
Towards a Typology of Lexical Semantic Derivation Models: Linguistic and Psycholinguistic Aspects
}

\section{Типологія моделей семантичної деривації лексики: лінгвістичний та психолінгвістичний аспекти}

\author{
Oleh Demenchuk \\ DSc. in Philology, Professor, \\ Head of the Department of Romance \\ and Germanic Philology

\section{Олег Деменчук} \\ доктор філологічних наук, \\ професор, завідувач кафедри \\ романо-германської філології \\ E-mail: oleh.demenchuk@gmail.com \\ https://orcid.org/0000-0002-3218-6693 \\ ResearcherID: A-9356-2018
}

Rivne State University

of Humanities

31, Plastova Str., Rivne,

Ukraine, 33000
Рівненський державний гуманітарний університет вул. Пластова, 31, Рівне, Україна, 33000

Original manuscript received December 30, 2019

Revised manuscript accepted September 28, 2020

\section{ABSTRACT}

Objective. The paper focuses on lexical semantic derivation models and the ways they are explicated in experiential vocabulary. The study substantiates linguistic and psycholinguistic features of the models in the contrastive aspect (based on the Ukrainian and Polish languages).

Materials and Methods. The material for the analysis is the Ukrainian and Polish adjectives-stimuli that represent the concepts of experiential situation. The psycholinguistic validity of the models is verified based on the results of associative experiments. The results are supposed to help establish types of associations that underlie the experiential vocabulary extensions.

Results. The study appeals to the conceptions that uphold the idea of a dynamic conceptualization of the world of discourse (of a certain situation or its fragment). 
On that ground, the lexical semantic derivation models are considered as theoretical constructs that represent information on derivational strategies in Ukrainian and Polish. Such an approach has allowed not only to reveal cognitive mechanisms that underlie lexical (experiential) items' semantic extensions but also to systematize the semantic shifts that occur in the contrasted languages. The extensions are considered within four lexical semantic derivation models: componential (the level of semantic components and their configurations), actantial (the level of predicate-actant structures), topological (the level of image-schema transformations) and constructional (the level of lexical constructions).

Conclusions. The results show the relevance of both linguistic and psycholinguistic modelling in analysis of lexical semantic derivation. The choice of a semantic derivation strategy correlates with an informant's response to a word-stimulus. The similarities and differences in semantic shifts are determined by constraints that set limits on the target situation extensions.

Key words: semantic derivation, model, experiential, situation concept, contrastive.

\section{Introduction}

Lexical semantic derivation modelling stems from a very long tradition, which underwent developments from historical (diachronic) to compositional, constructional, cognitive and typological semantics studies. Within the indicated approaches, characteristics of regular semantic shifts have been ascertained (Traugott \& Dasher, 2005; Boleda, Schulte \& Badia, 2012; Narrog, 2012), mechanisms of lexical items' semantic development have been established (Kustova, 2004; Vanhove, 2008), dynamic models in lexical semantics have been characterized (Paducheva, 2004), types of argument alternations have been elaborated (Levin, 2015), features of semantic associations, occurring within constructions (including the cases of grammaticalization) have been considered (Goldberg, 1995; Eckardt, 2011; Traugott, 2011), typological features of semantic shifts in related and non-related languages have been revealed (Zaliznyak, 2013; Juvonen \& Koptjevskaja-Tamm, 2016).

Of paramount importance at present is the issue of combining methodologically adjacent approaches on semantic derivation modelling. The relevance of such an approach is determined by the universal and integral nature of semantic derivation: (a) regular semantic shifts are found in many (if not in all) languages of the world, irrespective of their phylogenic and cultural differences (Wierzbicka, 1992), cf: 
«Polysemy is in all probability a semantic universal inherent in the fundamental structure of language» (Ullmann, 1963: 183);

(b) semantic shifts are the same at any linguistic level (lexical, wordbuilding, grammatical), as they use common semantic mechanisms (Rakhilina, 2002: 372); (c) semantic shifts are psychologically valid (Radden \& Kövecses, 1999: 25), as lexical ambiguity is considered «a central problem of psycholinguistics» (Klepousniotou, Titone \& Romero, 2008: 1534), cf.:

«From a psychological and anthropological perspective, contiguity (and similarity/contrast) seem to be absolutely fundamental associative relationships» (Koch, 1999: 144).

According to the original hypothesis, the modelling of a linguistic item's semantics is realized through a sampling of alternative, hierarchically established semantic dimensions. On that ground, the models of lexical semantic derivation are interpreted as theoretical constructs that represent various ways a certain situation or its fragment is reconceptualized. Within cross-linguistic studies, the models of lexical semantic derivation are supposed to reveal the ways the information on the worldview changes (shifts) is encoded and distributed in lexical semantics of related and non-related languages. Such an approach agrees with the idea of a segmentation of the physical continuum

«within which languages may draw either the same or a different number of boundaries and within which they may draw the boundaries at the same or different places» (Lyons, 1968: 58).

The purpose of the paper is to characterize the types of lexical semantic derivation models and to substantiate the psycholinguistic validity of the models in the related (Ukrainian and Polish) languages.

The purpose is fourfold:

- to represent a methodological background and method for the analysis of lexical semantic derivation models;

- to characterize lexical semantic derivation models and to establish the ways they are explicated in the Ukrainian and Polish languages;

- to substantiate the psycholinguistic validity of lexical semantic derivation models in the contrasted languages;

- to outline the prospects for the study of lexical semantic derivation models. 


\section{Methodological Background and Method}

The study of lexical semantic derivation models is presumably based on the following methodological prerequisites: (a) lexical semantic derivation models are models of situations; (b) a model of situation represents the content of a lexical item through a sampling of a multidimensional situation concept that encodes information on the ways a situation is construed; (c) a situation is construed based on the reconceptualization strategies a designator resorts to - identificational, evaluative, associative, etc. (those strategies determine the relations between the source and target states of affairs).

Lexical semantic derivation models are considered to correlate with a set of alternative, hierarchically established semantic dimensions the aspects that specify the way the information on a situation reconceptualization is distributed in the semantic space of a lexical item. We claim the information to be distributed within four types of lexical semantic derivation models - componential, actantial, topological and constructional.

In order to substantiate the psycholinguistic validity of the models in the contrasted languages, we shall apply to the method of associative experiment. The experiment is supposed to establish (verify) types of semantic associations, as well as to reveal general cognitive mechanisms that underlie the experiential items' semantic extensions.

\section{Results and Discussion}

We will make use of the results of the word association tests, carried out by the Department of Computational Linguistics at Jagiellonian University in Kraków (http://www.klk.uj.edu.pl/sssjp/en); see also (Gatkowska, 2017), and of those conducted at Nizhyn Teachers University (http://it-claim.ru/Projects/ASIS/SAS /index.html).

The material for the analysis is the Ukrainian and Polish adjectivesstimuli that represent various experiential situations, cf.: білий 'white', важкий 'heavy', черствий 'stale' vs. biaty 'white', ciężi 'heavy', czerstwy 'stale'. The choice is determined by the specific feature of an adjective as a semiological subclass of words - adjectives consist of a list of argument positions and reveal dependency that usually holds 
between the predicate and its actants (Dik, 1992: 21). This suggests the relational (situational) character of the semantic structure of an adjective.

The analysis provides for the evaluation of the responses in the highlight of reconceptualization strategies. The responses are paradigmatic and syntagmatic associations that characterize a situation by a certain semantic feature (paradigmatic associations) (see Table 1):

Table 1. Paradigmatic associations of the experiential terms білий vs. biaty, важкий vs. сiężki, черствий vs. czerstwy

\begin{tabular}{|c|c|c|}
\hline $\begin{array}{c}\text { Stimuli / } \\
\text { Responses }\end{array}$ & Ukrainian & Polish \\
\hline $\begin{array}{l}\text { білий } \\
\text { vs. } \\
\text { biaty }\end{array}$ & $\begin{array}{l}\text { чорний 'black' (29), чистий 'pure' (17), світлий } \\
\text { 'light' (5), добрий 'kind' (4), байдужий 'indifferent', } \\
\text { гарний 'beautiful', жовто-блакитний 'yellow-and- } \\
\text { blue', невизначений 'vague', неприродний 'unnatural', } \\
\text { прозорий 'transparent', порожній 'empty', свіжий } \\
\text { 'fresh', сірий 'grey', скупий 'greedy' (1) }\end{array}$ & $\begin{array}{l}\text { czarny 'black' (131), } \\
\text { jasny 'light' (13), } \\
\text { pusty 'empty' }\end{array}$ \\
\hline $\begin{array}{c}\text { важккий } \\
\text { vs. } \\
\text { ciężki }\end{array}$ & $\begin{array}{l}\text { хворий 'ill' (5), великий 'large', швидкий 'rapid', } \\
\text { молодий 'young', поганий 'bad', слабкий 'weak' (1) }\end{array}$ & $\begin{array}{l}\text { lekki 'light' (112), } \\
\text { trudny 'hard' }\end{array}$ \\
\hline $\begin{array}{l}\text { черствий } \\
\text { vs. } \\
\text { czerstwy }\end{array}$ & гpoui 'money' (1) & świeży 'fresh' \\
\hline
\end{tabular}

or by an actantial position of a participant (syntagmatic associations) (see Table 2):

Table 2. Syntagmatic associations of the experiential terms білий vs. biały, важкий vs. ciężki, черствий vs. czerstwy

\begin{tabular}{|c|c|c|}
\hline Stimuli & Ukrainian & Polish \\
\hline $\begin{array}{c}\text { білий } \\
\text { vs. } \\
\text { bialy }\end{array}$ & 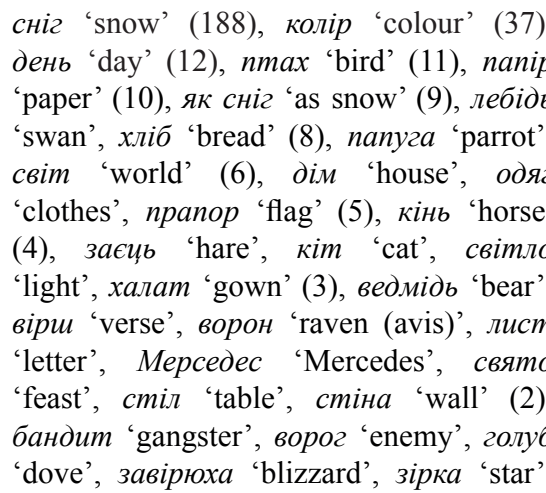 & $\begin{array}{l}\text {, śnieg 'snow' (181), orzeł 'eagle' (137), } \\
\text { kolor 'colour' (111), fartuch 'apron' } \\
\text { (66), ser 'cheese' (47), kruk 'raven } \\
\text {, (avis)' (43), cukier 'sugar' (39), dom } \\
\text { 2'house' (34), mleko 'milk' (30), miś } \\
\text {, 'bear' (28), obrus 'tablecloth' (26), } \\
\text { dym 'smoke' (21), bielinek 'cabbage } \\
\text {, white butterfly' (20), koń 'horse' (17), } \\
\text { hiet 'fang' (15), dzień 'day' (13), } \\
\text { papier 'paper' (11), baran 'ram' (9), } \\
\text {, owca 'ewe' (5), lerarz 'doctor' (4), } \\
5 \text { motyl 'butterfly' (4), puch 'down', } \\
\text {, symbol 'symbol' }\end{array}$ \\
\hline
\end{tabular}


іній 'hoarfrost', капелюх 'hat', кімната 'room', кокаїн 'cocaine', лелека 'stork', місяиь 'mоon', молоко 'milk', мороз 'frost', ніч 'night', хмара 'cloud', орел 'eagle', перстень 'seal ring', півень 'cock', пісок 'sand', пляма 'spot', постіль 'bedclothes', ранок 'morning', рушник 'towel', світанок 'dawn', светр 'sweater', смерть 'death', собака 'dog', сорочка 'shirt', спокій 'quiet', сукня 'dress', танещь 'dance', фарба 'paint', фартух 'apron', хлопець 'boy', ивіт 'blossom', иукор 'sugar', черевик 'boot', чуб 'forelock', шарф 'scarf', шкіра 'skin', шлях 'way', яйще 'egg', як смерть 'as death' (1)

важский робота 'work' (41), справа 'business' praca 'work' (735), orzech 'nut' (тяжккий) (8), життя 'life' (5), війна 'war', (617), choroba 'disease' (37), glowa vs. cмepmb 'death' (4), вmpama 'loss', 'head' (31), stót 'table' (13), dywan ciężki обман 'deceit' (3), гроші 'money', день 'carpet' (12), mlotek 'hammer', 'day', початок 'beginning' (2), голова ręka 'hand' (11), kobieta 'woman' 'head', двері 'door', земля 'soil', зло (6), Biblia 'Bible', stopa 'foot' (2), 'evil', кохання 'love', ранок 'morning', kamien 'stone', młot 'sledge hammer', хліб 'bread', ходьба 'walking', час dzień 'day', ciężar 'load', odważnik 'time', шлях 'way' (1) 'weight', przedmiot 'object', los 'fate', mebel 'furniture', głaz 'rock', sprzęt 'equipment', bagaż 'luggage', stoń 'elephant', ołów 'lead', orzech do zgryzienia 'nut to crack', żywot 'life, existence', grzech 'sin'

черствий хліб 'bread' (2), душа 'soul' (1) vs. czerstwy chleb 'bread' (729), dowcip 'wit', mężczyzna 'man', żart 'joke'

The interpretation of the associations provides for establishing: (a) shifts that occur at the level of semantic components and their configurations (componential model); (b) shifts that occur at the level of predicate-actant structures (actantial model); (c) shifts that occur at the level of image-schema transformations (topological model); (d) shifts that occur at the level of lexical constructions (constructional model).

The componential model provides for the associative shifts that occur between the experiential items' semantic components and their configurations.

The associative experiments in Ukrainian and Polish show that the primary responses to the stimuli are reduced to «typical», either 
«prototypical» (of associations about the prototypical referents that are supposed to represent common experiences of people around the world), cf.: білий (сніг) vs. biały (śnieg), cf.: білий «який має колір снігу» vs. biały «mający barwę, taką jak śnieg»; важкий (великий) vs. ciężki (ciężar), cf.: важкий «який має велику вагу» vs. ciężki «mający duży ciężar»; черствий (хліб) vs. czerstwy (chleb), cf.: черствий «який став твердим, несвіжим, засох (про хліб, борошняні вироби)» vs. czerstwy «o pieczywie: suchy, twardy, nieświeży», etc., or «stereotypical» (of the associations with the nearest analogues in human activities and their results), cf.: важка (праия; хворий) vs. ciężka (praca, choroba), cf.: важкий «який вимагає великого напруження, великих зусиль для здійснення, проведення, подолання і т. ін.» vs. ciężki «wymagający dużo trudu, wysiłku; mozolny, trudny do wykonania» senses. Henceforth, the situation concept extends to the semantics of «non-typical» states of affairs (see Fig. 1): (a) perceptual, cf.: білий (стіна, лелека, хмара, etc.) vs. biały (koń, obrus, jeleń); ciężki (kamien, młot, odważnik, etc.); (b) physical (physiological), cf.: важкий (хворий; ходьба) vs. ciężka (głowa); (c) cognitive (intellectual), cf.: ciężki (orzech do zgryzienia; twardy), cf. twardy orzech do zgryzienia «trudny problem do rozstrzygnięcia, trudna sprawa do załatwienia»; (d) identificational (of a conventionalized characteristics of an object, i.e. its individualizing or distinctive feature), cf.: білий (ніч, світ, хліб, etc.) vs. biały (dzień, ser); (e) symbolic (of the associations with a stereotypical phenomena, characteristic of any culture, as of a formal authoritative statement or summary of the religious belief), cf.: важкий (обман) vs. ciężki (grzech), cf. grzech ciężki «w teologii chrześcijańskiej: całkowite i dobrowolne odwrócenie się od Boga poprzez złamanie jego zakazu w sprawach wielkiej wagi, niosące ze sobą ryzyko wiecznego potępienia»; білий (бандит, ворог, одяг, прапор, свято) vs. biały (orzet, symbol); (f) evaluative (of, pertaining to, or tending to evaluation), cf.: білий (гарний, байдужий; чорний) vs. biały (сzаrny); важкий (день, робота, ранок, etc.) vs. ciężki (praca, dzień, ̇̇ywot); білий (прозорий, чистий) vs. biaty (jasny). It is worth noting that the evaluative associations may not coincide in the contrasted languages. For example, in the Ukrainian language the situation concept reveals a broader extension what concerns the evaluation of person's characteristics, cf.: черствий (душа). In Polish, the situation is rather gender-marked, cf.: czerstwy mężczyzna. In order to make up for the extension, the Polish language construes the 
situation either by means of a different term, cf.: oschly «nieskłonny do wzruszeń; nieczuły, oziębły, obojętny», or by idiomatic expressions like człowiek o twardym, zimnym sercu «człowiek nieczuły, niewzruszający się łatwo».

\section{TYPICAL $\rightarrow$ NON-TYPICAL}

Fig. 1. The extensions within the componential model

The actantial model is reduced to shift-in-focusing strategies. The strategies provide for the redistributions of attention on the situation participants, when one of the participants is foregrounded and focused upon, and the other is backgrounded and defocused (see Paducheva, 2004; Iriskhanova, 2014). The redistributions of attention may result in: (a) increase or decrease of obligatory participants in the target situation; (b) changes of the participant's referential status or deictic characteristics. These characteristics determine the way a situation concept extends. As for the concept of experiential situation, the extensions occur on a «parameter» scale - from parametric entities to non-parametric ones (see Fig. 2):

\section{PARAMETRIC $\rightarrow$ NON-PARAMETRIC}

Fig. 2. The extensions within the actantial model

In differentiating between the parametric and non-parametric entities, we apply to the notion of «organic states», cf.:

«The organic states are intrinsic to the meaning of a predicate: the situation is conceptualized as an integral feature of its cardinal participant, and it is not a result of some other event (stone is heavy, grass is green). The derived states, on the contrary, are conceptualized as those obtained from a certain process or activity» (see Kibrik, 1992: 136).

From this viewpoint, the associations like важкий (великий; дверi, земля) vs. ciężki (głaz, mebel, słoń, etc.); білий (колір, папір, птах; світлий, etc.) vs. biaty (kolor, papier, obrus; jasny, etc.); черствий (хліб) vs. czerstwy (chleb) are conceptualized as «parametric» states of affairs. The states are identified so based on the observed parameters (size, magnitude, bulk, dimension, hue, brightness, etc.) an object 
is attributed to. The situation reveals the presence of an experiencerparticipant (the semantic role of Perceiver) who is supposed to experience an object by its «colour», "heaviness» or «staleness» parameter. On the contrary, the situations like ciężki (ołów); білий (ніч, світ, хліб, etc.) vs. biały (dzień, ser); білий (неприродний, пустий, скупий, etc.) vs. biały (pusty) are considered non-parametric. The reconceptualization provides for the changes in the experiencer-participant's referential status - the participant acquires the features either of Cognizer, cf.: ciężki (orzech do zgryzienia), or of Emoter, cf. черствий (душа) vs. czerstwy (dowcip, $\dot{z} a r t$, mężczyzna).

The topological model is reduced to the transformations that occur within basic image-schemas - the recurring patterns of our sensorymotor experience by means of which we make sense of that experience and reason about it (Johnson, 1987: 126). The partial list of schemata includes: PATH (a force vector moving from a source to terminal point), COMPULSION (experience of being moved by external forces), COUNTERFORCE (the head-on meetings of forces), BLOCKAGE (obstacles that block or resist our force), ENABLEMENT (a potential force vector and an absence of barriers or blocking counterforce), REMOVAL OF RESTRAINT (an open way or path, which makes possible an exertion of force), etc.

The associative experiments show that the concept of a prototypical experiential situation in Polish and Ukrainian is characterized by the image-schema of SCALE. The image-schema encodes the information either on a potentially experienced value (i.e. value, experienced under certain conditions), cf.: важкий «тяжкий; в якому відчувається велика вага»: важкий (дверi) vs. ciężki «dużo ważący»: ciężki (dywan); biały «mający bardzo jasną barwę» biały (jasny), or the opposite value, cf.: білий (чорний) vs. ciężki (lekki); biały (czarny); czerstwy (świeży). It is intensity of sensation that stands for the experienced value. For the experiencer, the value is a kind of a latent force that may become manifest in case of an actual experience. For instance, 'light' (bright, shining, luminous) may be conceptualized as 'white', if it is opposed to another value, cf.: білий (сірий): білий пісок vs. сірий пісок, and a 'thing' may be qualified 'heavy', in case the experiencer gets in touch with it, cf.: ciężki (przedmiot).

From this viewpoint, the extension of the experiential situation would be considered in terms of force dynamics interpretations - from a potential (latent) force to a non-potential (actual) one (see Fig. 3): 


\section{POTENTIAL $\rightarrow$ NON-POTENTIAL}

Fig. 3. The extensions within the topological model

A non-potential force is qualified as an active entity, which may impose resistance, power, influence, etc. (features that underlie a certain image-schematic concept - vide supra) on an experiencer. For example, the situation of «heaviness» reveals the extension towards the imageschema of BLOCKAGE, as the object is conceptualized as a «resisting» entity, cf.: ciężki «dający się z trudem podnieść», cf.: ciężki (bagaż). In both languages, the image-schema of COMPULSION underlies the extension towards a stereotypical situation - vide supra, cf.: важкий (робота), cf.: важкий «який вимагає великого напруження, великих зусиль для здійснення, проведення, подолання i т. ін.» vs. ciężki (praca), cf.: ciężki «wymagający dużo trudu, wysiłku». The languages also reveal some specific extensions within the realm of image-schematic concepts. For example, the extension towards the evaluative situation in Polish is provided within the image-schema of COMPULSION, cf.: ciężki «uciążliwy (wymagający wysiłku)»: ciężki (los, żywot), whereas in Ukrainian the situation is likely to be construed within the schema of CONTAINER (FULL-EMPTY), cf.: важкий «сповнений труднощів, нестатків, горя»: важкий (життя, час, илях).

The transformational configurations may also be modelled through a sampling of a trajectory-landmark alignment structure (Langacker, 1987: 227). Thus, in respect to the associations важкий (дверi) vs. ciężki (glaz), the Trajector and Landmark profile the experiential situation within the relation: external stimulus (perceptual space) vs. inner reaction (evaluative perception). The Landmark is interpreted as an indicator of a perceptual quality of an object (e.g. an object might look massive and solid), whilst the Trajector - as an (atemporal) feature of evaluative perception (the object is valued as being heavy), cf. важкий «вигляд якого (значні розміри, масивність, густота і т. ін.) свідчить про велику вагу» vs. ciężki «о budowli, stroju itp.: zbyt masywny». The shift of the Trajector relative to the perceptual space provides for the changes in the space evaluation (e.g. getting in touch with an object, the object might prove to be light), cf. the responses важкий (легкий) vs. ciężki (lekki). The Landmark also represents the symbolic space of a «heavy» object, cf. the association ciężki (grzech). The Trajector's shift relative to the space indicates the changes in the degree of evaluation, 
cf. важкий (обман) «значний за ступенем, силою прояву; великий, значний, який призводить до поганих наслідків».

The constructional model is reduced to the construction content, «associated $\langle\ldots\rangle$ with semantic structures which reflect scenes basic to human experience» (Goldberg, 1995: 5).

The semantic structures are argument structures (sort of $X$ causes $Y$ to receive $Z$ ) that represent a certain dynamic scene, in which argument roles are interpreted as functions derived from the event, e.g.: someone causing something to move or change state; someone experiencing something; something moving, etc. In terms of Vandeloise's «complex primitives» (Vandeloise, 1987), a scene is viewed as a set of propositions, encoding and distributing information on three experiential dimensions: perception, kinetics and interaction. Among those, a purposive dimension (interaction) is considered the most relevant to human beings (see Correa-Beningfield et al., 2005: 355-356).

The analysis of semantic derivation models within the constructional approach proceeds from the assumption that

«it is natural for constructions to be associated with a central sense, and with extensions from that sense» (Goldberg, 1995: 203).

The analysis case would be a «simile» construction as white as $X$ (білий як сніг vs. biaty jak śnieg). The central sense of the construction encodes information on an identificational situation within the following argument structures: (a) $\mathrm{X}$ considers $\mathrm{Y}$ as similar to $\mathrm{Z}$ 's (evaluation); (b) X considers $\mathrm{Y}$ in a canonical way (interaction), cf.: Костел потребував оздоби, і ксьондзи гадали, що від присутності Наясвятішої Панни там стане ясніше, бо ж камінь білий як сніг vs. Marylka ma na sobie biała jak śnieg sukienkę. The extension towards the situation of physical (physiological) state (білий як стіна, як смерть vs. biaty jak papier) reveals the changes in the argument structure's configuration: (a) X considers $\mathrm{Y}$ as similar to Z's (evaluation); (b) $\mathrm{X}$ considers $\mathrm{Y}$ in a non-canonical way (interaction), cf.: A Катря стоїть коло стіни, сама, як стіна, біла, - бачу - зомліває vs. Ме̨żсуzппа rąat pod szopq drzewo, na widok Tadeusza zrobit się biaty jak papier.

From this viewpoint, the extension of the experiential situation would be considered within a «purposive dimension» scale - from a canonical interaction to a non-canonical one (see Fig. 4): 


\section{$\mathrm{CANONICAL} \rightarrow$ NON-CANONICAL}

Fig. 4. The extensions within the constructional model

\section{Conclusions}

The performed study appeals to the conceptions that uphold the idea of a dynamic conceptualization of the world of discourse (of a certain situation or its fragment). The dynamic approach towards the study of experiential vocabulary aims to elaborate a system of lexical semantic derivation models. The models are considered to represent various types of semantic associations that underlie the development of experiential vocabulary's semantic paradigm.

Four types of lexical semantic derivation models are singled out - componential, actantial, topological and constructional. The componential model provides for the associative shifts that occur within the experiential items' semantic components and their configurations. The actantial model is reduced to the shift-in-focusing strategies based on the changes of the situation participants. The topological model provides for the image-schema transformations that underlie the extensions at the level of image-schematic concepts. The constructional model is reduced to the extensions, occurring within the experiential items' argument structures.

The results of associative experiments have confirmed the psycholinguistic validity of the models. It has been established that in responding to a stimulus, informants apply to different semantic derivation strategies. From this viewpoint, the models represent various ways the concept, encoded in the semantics of experiential vocabulary, extends: from typical to non-typical state of affairs (componential model), from parametric to non-parametric entity (actantial model), from potential to non-potential force (topological model), from canonical to non-canonical interaction (constructional model).

The models have proved to be effective means for analyzing semantic derivation strategies in cross-linguistic studies. The analysis has revealed similarities and differences in the extensions of experiential vocabulary in the Ukrainian and Polish languages. It has been established that extensions in Polish are more localized as they reveal some constraints in the target situation extensions - they mostly cover 
semantic zones that encode information on person's internal (perceptual, cognitive, identificational) systems. In the Ukrainian language, the constraints are somewhat loosened, which enables it to extend to the boundaries of both external and internal systems.

It is necessary to carry out further research into semantic derivation modelling in comparative, historical and typological aspects. The choice of the aspects is determined by the tendency of modern semantic studies to a profound analysis of the semantic shifts in related and non-related languages.

\section{References}

Boleda, G., Schulte, S., \& Badia, T. (2012). Modeling regular polysemy: A study on the semantic classification of Catalan adjectives. Computational Linguistics, 38, 3, 575-616. https://doi.org/10.1162/COLI_a_00093

Correa-Beningfield, M., Kristiansen, G., Navarro-Ferrando, I., \& Vandeloise, C. (2005). Image schemas vs. «Complex Primitives» in cross-cultural spatial cognition. In B. Hampe (Ed.), From perception to meaning: Image schemas in cognitive linguistics (pp. 343-368). Berlin; N. Y.: Mouton de Gruyter. https://doi. org/10.1515/9783110197532.4.343

Dik, S. (1992). Functional grammar in Prolog. An integrated implementation for English, French, and Dutch. Berlin, New York: Walter de Gruyter. https://doi. org/10.1515/9783110850451

Eckardt, R. (2011). Grammaticalization and semantic change. In H. Narrog, \& B. Heine (Eds.), The Oxford handbook of grammaticalization (pp. 389-400). Oxford: Oxford University Press. https://doi.org/10.1093/oxfordhb/9780199586783.013.0031

Vanhove, M. (Ed.). (2008). From polysemy to semantic change. Towards a typology of lexical semantic association. Amsterdam, Philadelphia: John Benjamins Publ. https://doi.org/10.1075/slcs.106

Gatkowska, I. (2017). Eksperymentalna sieć leksykalna języka polskiego. Kraków: Wydawnictwo Uniwersytetu Jagiellońskiego [in Poland].

Goldberg, A.E. (1995). Constructions: A construction grammar approach to argument structure. Chicago: University of Chicago Press.

Iriskhanova, O.K. (2014). Igry fokusa v yazyke. Semantika, sintaksis i pragmatika defokusirovaniya [Games of focus in the language. Semantics, syntax and pragmatics of defocusing]. Moscow: Yazyki slavyanskoy kultury [in Russian].

Johnson, M. (1987). The body in the mind: The bodily basis of meaning, imagination, and reason. Chicago: The University of Chicago Press. https://doi.org/10.7208/ chicago/9780226177847.001.0001

Kibrik, A.E. (1992). Ocherki po obshchim i prikladnym voprosam iazykoznaniia (universalnoe, tipovoe $i$ spetcificheskoe $v$ iazyke) [Sketches on general and applied issues of linguistics (universal, typical and specific in language)]. Moscow: MGU [in Russian].

Klepousniotou, E., Titone, D., \& Romero, C. (2008). Making sense of word senses: The comprehension of polysemy depends on sense overlap. Journal of 
Experimental Psychology: Learning, Memory, and Cognition, 34, 6, 1534-1543. https://doi.org/10.1037/a0013012

Koch, P. (1999). Frame and contiguity: On the cognitive bases of metonymy and certain types of word formation. In K-U. Panther \& G. Radden (Eds.), Metonymy in language and thought (pp. 139-167). Amsterdam, Philadelphia: John Benjamins Publ. dx. https://doi.org/10.1075/hcp.4.09koc

Kustova, G.I. (2004). Tipy proizvodnykh znacheniy $i$ mekhanizmy yazykovogo rasshireniya [Types of derived values and mechanisms of language extension]. Moscow: Yazyki slavyanskoy kultury [in Russian].

Langacker, R.W. (1987). Foundations of cognitive grammar. Theoretical prerequisites. Stanford, CA: Stanford University Press.

Levin, B. (2015). Semantics and pragmatics of argument alternations. Annual Review of Linguistics, 1, 63-83. https://doi.org/10.1146/annurev-linguist-030514-125141

Lyons, J. (1968). Introduction to theoretical linguistics. Cambridge: Cambridge University Press. https://doi.org/10.1017/CBO9781139165570

Narrog, H. (2012). Modality, subjectivity, and semantic change. A cross-linguistic perspective. Oxford: Oxford University Press. https://doi.org/10.1093/acprof:o so/9780199694372.001.0001

Paducheva, E.V. (2004). Dinamicheskie modeli v semantike leksyki [Dynamic models in the semantics of vocabulary]. Moscow: Yazyki slavyanskoy kultury [in Russian].

Radden, G., \& Kövecses, Z. (1999). Towards a theory of metonymy. In K-U. Panther \& G. Radden (Eds.), Metonymy in language and thought (pp. 17-60). Amsterdam, Philadelphia: John Benjamins Publ. https://doi.org/10.1075/hcp.4.03rad

Rakhilina, E.V. (2002). Osnovnye idei kognitivnoy semantyki [The main ideas of cognitive semantics]. In A.A. Kibrik, I.M. Kobozeva \& I.A. Sekerina (Eds.), Sovremennaya amerikanskaya lingvistika: Fundamentalnye napravleniya. (pp. 370-389). Moscow: Editorial URSS [in Russian].

Juvonen, P., \& Koptjevskaja-Tamm, M. (Eds.). (2016). The lexical typology of semantic shifts. Berlin, Boston: Walter de Gruyter. https://doi.org/10.1515/9783110377675

Traugott, E.C. (2011). Grammaticalization and mechanisms of change. In H. Narrog \& B. Heine (Eds.), The Oxford Handbook of Grammaticalization (pp. 19-30). Oxford: Oxford University Press. https://doi.org/10.1093/ oxfordhb/9780199586783.013.0002

Traugott, E.C., \& Dasher, R.B. (2005). Regularity in semantic change. Cambridge: Cambridge University Press.

Ullmann, S. (1963). Semantic universals. Universal of language. In J.H. Greenberg (Ed.), Report of a conference held at Dobbs Ferry, New York (April 13-15, 1961), (pp. 172-207). Cambridge, MA: The M.I.T. Press.

Vandeloise, C. (1987). Complex primitives in language acquisition. Belgian Journal of Linguistics, 2(1), 11-36. https://doi.org/10.1075/bjl.2.02van

Wierzbicka, A. (1992). Semantics, culture, and cognition: Universal human concepts in culture-specific configurations. Oxford, New York: Oxford University Press.

Zaliznyak, Anna A. (2013). Russkaya semantika v tipologicheskoy perspektive [Russian semantics in typological perspective]. Moscow: Yazyki slavyanskoy kultury [in Russian]. 


\section{АНОТАЦІЯ}

Мета. У статті схарактеризовано типи моделей семантичної деривації лексики, визначено способи експлікації моделей у семантиці експерієнціальної лексики, представлено лінгвістичні та психолінгвістичні характеристики моделей у зіставному аспекті (на матеріалі української та польської мов).

Матеріал та процедура дослідження. Матеріалом дослідження слугують українські та польські прикметники-стимули, які характеризують зміст концептів експерієнціальної ситуації. Для психолінгвістичного обгрунтування моделей семантичної деривації застосовано асоціативні експерименти. Мета експериментів - визначити типи асоціацій, на основі яких, як передбачається, реалізуються стратегії семантичних розширень експерієнціальної лексики в зіставлюваних мовах.

Результати. Проведене дослідження апелює до концепцій, які обстоюють ідею динамічної концептуалізації світу дискурсу (певної ситуації або ії фрагмента). На цій підставі моделі семантичної деривації експерієнціальної лексики осмислюються як теоретичні конструкти, які кодують інформацію про дериваційні стратегії в українській та польській мовах. Такий підхід дозволив не лише визначити когнітивні механізми, які регулюють семантичні переходи експерієнціальної лексики, а й систематизувати характеристики семантичних розширень у зіставлюваних мовах. Виокремлено чотири типи моделей семантичної деривації: компонентний (рівень семантичних компонентів та їх конфігурацій), актантний (рівень предикатно-актантних структур), топологічний (рівень образ-схематичних трансформацій) та конструкційний (рівень лексичних конструкцій).

Висновки. Результати засвідчують релевантність лінгвістичного та психолінгвістичного моделювання семантичної деривації лексики. Вибір стратегії семантичної деривації корелює з реакцією інформанта на словостимул. Подібності та розбіжності семантичних переходів зумовлені чинником обмежень в обсязі розширень цільових ситуацій.

Ключові слова: семантична деривація, модель, експерієнціальний, концепт ситуації, зіставний.

Деменчук Олег. Типология моделей семантической деривации лексики: лингвистический и психолингвистический аспекты

\section{АННОТАЦИЯ}

Цель. В статье охарактеризованы типы моделей семантической деривации лексики, определены способы экспликации моделей в семантике экспериенциальной лексики, представлены лингвистические и психолингвистические характеристики моделей в сопоставительном аспекте (на материале украинского и польского языков).

материал и процедура исследования. Материалом для исследования послужили украинские и польские имена прилагательные-стимуль, 
The Role of Personal Internet Orientation in the Process...

характеризующие содержание концептов экспериенциальной ситуации. Для психолингвистического обоснования моделей семантической деривации использованы ассоциативные эксперименты. Цель экспериментов определить типы ассочиаций, на основе которых, как предполагается, реализуются семантические расширения экспериенциальной лексики в сопоставляемых языках.

Результаты. Проведенное исследование аппелирует к концепциям, отстаивающих идею динамической концептуализации мира дискурса (определенной ситуации или ее фрагмента). На этом основании модели семантической деривации экспериенциальной лексики осмысливаются как теоретические конструкты, кодирующие информацию о деривационных стратегиях в украинском и польском языках. Такой подход позволил не только определить когнитивные механизмы, регулирующие семантические переходы экспериенциальной лексики, но и систематизировать характеристики семантических расширений в сопоставляемых языках. Выделены четыре типа моделей семантической деривации: компонентный (уровень семантических компонентов и их конфигураций), актантный (уровень предикатно-актантных структур), топологический (уровень образ-схематических трансформачий), конструкционный (уровень лексических конструкций).

Выводы. Результаты свидетельствуют о релевантности лингвистического и психолингвистического моделирования семантической деривации лексики. Выбор стратегии семантической деривации коррелирует с реакцией инфрорманта на слово-стимул. Сходства и различия семантических переходов обусловлены фактором ограничений в объеме расширений целевых ситуаций.

Ключевые слова: семантическая деривация, модель, экспериенциальный, концепт ситуации, сопоставительный. 